\title{
Performance Evaluation of Methanol Blend Fuel in SI Engine
}

\author{
Gohil Bhavdipsinh $\mathbf{J}^{1}$, GohilVirpalsinh B ${ }^{2}$, Rana Manan A ${ }^{3}$, Gandhi Pinkesh ${ }^{4}$, Mayank Sompura ${ }^{5}$ \\ 1, 2, 3, 4Student of Mechanical Engineering, Valia Institute of Technology, Bharuch, Gujarat Technological University, India \\ ${ }^{5}$ Head of Mechanical engineering Department, Valia Institute of Technology, Bharuch, Gujarat Technological University, India
}

\begin{abstract}
This paper describes some results of the research in the area of some additives like, methanol, ethanol etc. mixture in gasoline. The world research are become scare and measure crunch is found in case of crude oil and petroleum product. There are many alternative fuels like methanol, ethanol, biodiesel, biogas, butane, hydrogen, among them methanol has greater octane number, high heat of evaporation, oxygen contains by weight \% higher than other fuel which results that better engine performance and decrease in HC, HO, CO emission. This experimental performance test will be carried out at engine speed and variable load condition using various blends of MO to M50 fuel into the effect of methanol addition to gasoline of performance of IC engine. This method is used for the increasing efficiency of vehicle by adding different \% of methanol to the fuel and to decrease the pollution produce during the combustion process. Therefore alternative fuels source are sought to have alternative source for petrol without altering the coasting engine or slight change in the engine at low cost.
\end{abstract}

Keywords: Methanol, Methanol-gasoline blends, Exhaust emission, carburetion, fuel jet.

\section{Introduction}

As the time passes, it is believed that the petroleum products and crude oil will not be enough and will be costly. Various researches are going on for the improvement of fuel economy of engines. However as the demand and availability for petrol and diesel is somewhat unbalanced and there is a need to balance since that is mainly happened due to enormous increase in number of vehicles. If the same situation continues then the scenario will be more disastrous and petrol and diesel will be more costly and limited. With increased use and the depletion of fossil fuels, today more emphasis is given on the alternate fuels.

There is an essential need of alternate fuels in a way or other. Today intensive search for the alternative fuels for both spark ignition (SI) and compression ignition (CI) engines and it has been found out that the biomass derived fuels are suited for the alternate fuels. In spark ignition engines fuels like Methanol is suitable constituent for the petrol. They can be blended with petrol over a wide range of percentage according to the requirement.

Another reason for the need of alternate fuels for IC engines is the emission problems. Combined with other air polluting factors, the large number of automobiles is a major contributor to the air quality problems of the world. As these fuels cannot be run directly in the engines therefore these are blended with gasoline at various percentage. One of the main reasons for selecting these fuels is the similarity in the properties of these with gasoline and they are miscible with gasoline without any phase separation.

Methanol can be used in spark-ignition engine as a blend with gasoline. Since it has greater octane number, high heats of evaporation, Oxygen contents by weight \% performance and decrease in $\mathrm{HC}$, NO,CO emission.

\section{Details Description}

\subsection{Working Principle}

As the demand of petrol and petroleum products is getting increased day by day the petrol and diesel are becoming expensive and will be scarce in the future. The main reason for this situation is the increase in the number of vehicles and most of the crude oil is imported from other countries which control the larger oil fields. In order to make the situation look better various researches and experiments were done to replace the petrol and diesel with some suitable alternate fuel. Various fuels are found out to be potential candidates for both spark-ignition (SI) and compression ignition (CI) engines. When we specifically talk about spark-ignition engine (SI) biomass derived fuels having high octane value are the potential alternative fuel. It includes Methanol, Ethanol, Biogas, Butane etc.

Blending is a process of mixing two fluids of almost same characteristics properties by volume. Gasoline is blended with methanol by volume. These two fuels are readily mixes and do not lead to phase separation and their properties are similar and methanol is miscible with gasoline. The fuel blend is the replacement of petrol in the engine. Blending leads to less consumption of the petrol while operating at same conditions as that of standard petrol and it also leads to the improvement of brake thermal efficiency of the engine at the same time reduces the emission characteristics viz. CO emissions, $\mathrm{HC}$ emissions and $\mathrm{NO}$ emissions. It also improves the performance of the engine.

\subsection{System Components}

\section{1) Four Stroke SI Engine}

It is an internal combustion engine consists of following main parts: Crank Shaft, Crank, Connecting rod, Piston, Cylinder, Inlet Valve, Exhaust Valve, and Spark Plug.The Piston performs four strokes to complete one working cycle. 


\section{International Journal of Science and Research (IJSR) \\ ISSN (Online): 2319-7064}

Index Copernicus Value (2013): 6.14 | Impact Factor (2015): 6.391

The Four different strokes are 1. Suction stroke, 2. Compression stroke, 3.Power stroke, 4. Exhaust Stroke.

\section{2) Carburetor}

A carburetor is device that bladed air and fuel for an internal combustion engine. Carburetors have largely been supplanted in the automobile industry by fuel injection. They are still common on small engine for lawn mowers and other equipment. The carburetor works on Bernoulli's principal: the faster air moves, the lower its static pressure, and the higher its dynamic pressure. The throttle linkage does actuate carburetor mechanisms which meter the flow of air being pulled into the engine. The speed of this flow, and therefore its pressure, determine the amount of fuel drawn into the airstreams, special designed and features are needed to prevent fuel starvation during inverted flight.

\section{3) Air filter}

The combustion air filter prevents abrasive particulate matter from entering the engine's cylinders, where it would cause mechanical wear and oil contamination. Most fuel injected vehicles use a pleated paper filter element in the form of a flat panel. This filter is usually placed inside a plastic box connected to the throttle body with ductwork.

\section{4) Exhaust System}

Due to combustion of hydrocarbon of fuel, exhaust gases which mainly contains $\mathrm{H} 2 \mathrm{O}, \mathrm{CO} 2$, unburnt $\mathrm{HC}$, NOx, SO2, etc, This exhaust gases are useless and it must be came out from engine cylinder during exhaust stroke. The pipe through which it comes out is known as exhaust manifold. The exhaust system mainly contains exhaust manifold, muffler or silencer and tail pipe. Silencer is essential in exhaust system which reduces the noise level in exhaust, without silencer the noise of I.C engine is erratic with high amplitude.

\subsection{Schematic Diagram}

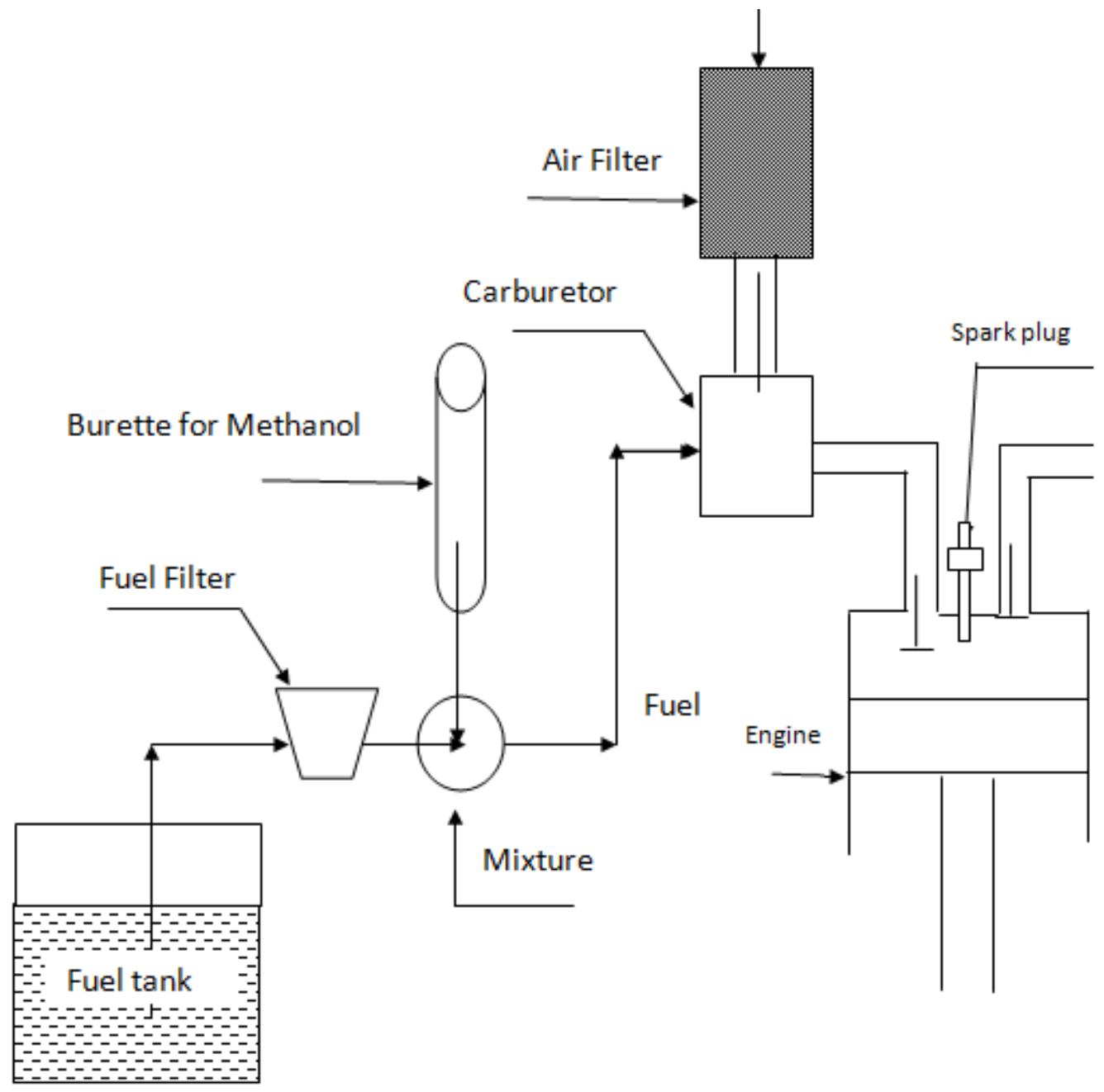

Figure 1: Schematic diagram of fuel intake system \& 4-stroke SI engine 


\section{International Journal of Science and Research (IJSR) \\ ISSN (Online): 2319-7064}

Index Copernicus Value (2013): 6.14 | Impact Factor (2015): 6.391

\subsection{Engine Specification:}

Table 1: Engine specification

\begin{tabular}{|c|c|}
\hline Vehicle name & Hero Honda splendor \\
\hline Type & Four Stroke SI Engine \\
\hline No. of cylinder & Single \\
\hline Maximum power & $6.15 \mathrm{KW}$ @ $8000 \mathrm{rpm}$ \\
\hline Start & Kick start \\
\hline No. of gear & Four \\
\hline Compression ratio & $9.9: 1$ \\
\hline Engine displacement & $97.2 \mathrm{cc}$ \\
\hline
\end{tabular}

\section{Actual Working Model}

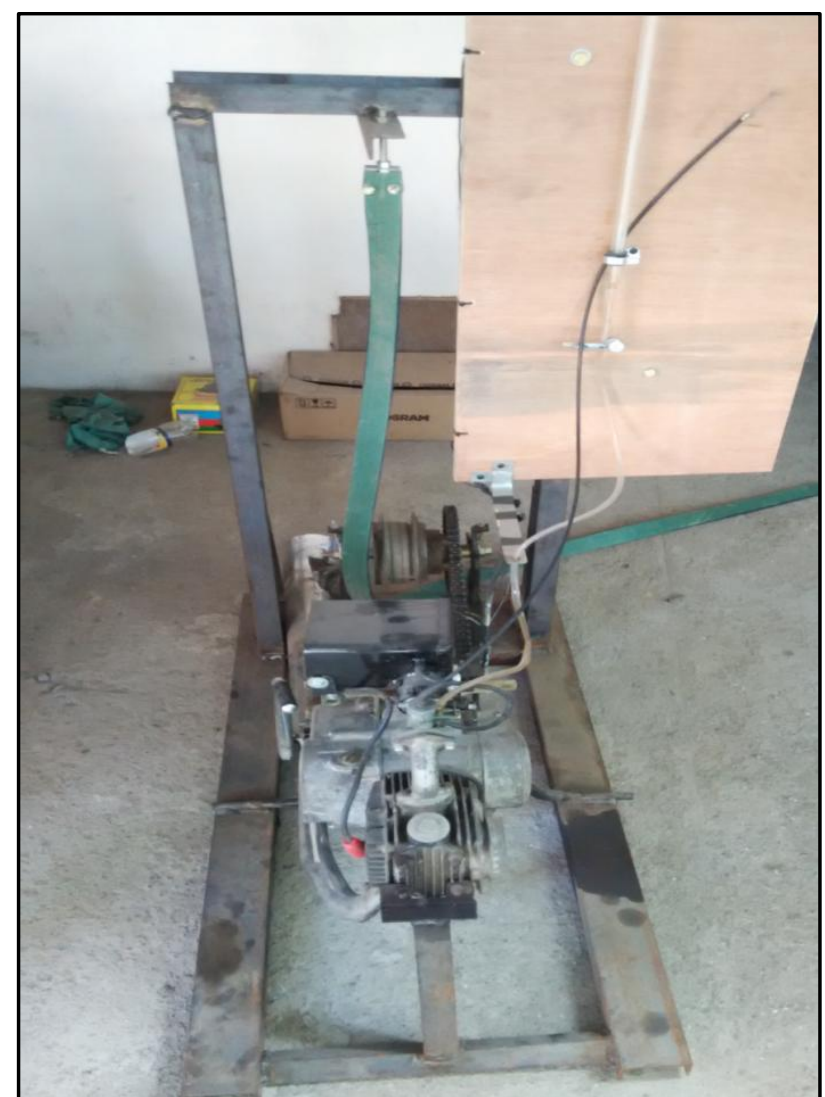

Figure 2: Actual working model of 4-stroke SI engine with methanol blend fuel

The engine was started by kick and worm up for a period of 10 to 20 minutes. Engine test were performed at constant speed. Before running the engine to a new fuel bend, it was allowed to run for sufficient time to consume the remaining fuel from previous experiment.

The experiment was performed at constant speed and constant load. Methanol gasoline blends used in experiment was $0 \%, 20 \%$, $50 \%$ volume of methanol. The parameters such as fuel consumption rate, brake power, brake thermal efficiency were estimated by standard equation.

\subsection{Graphical Representation}

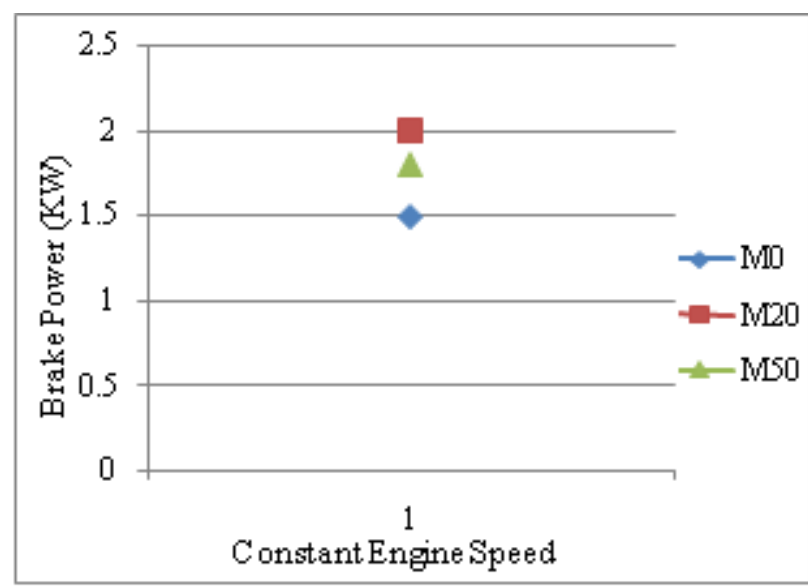

Figure 3: Variation of brake power with Constant engine speed]

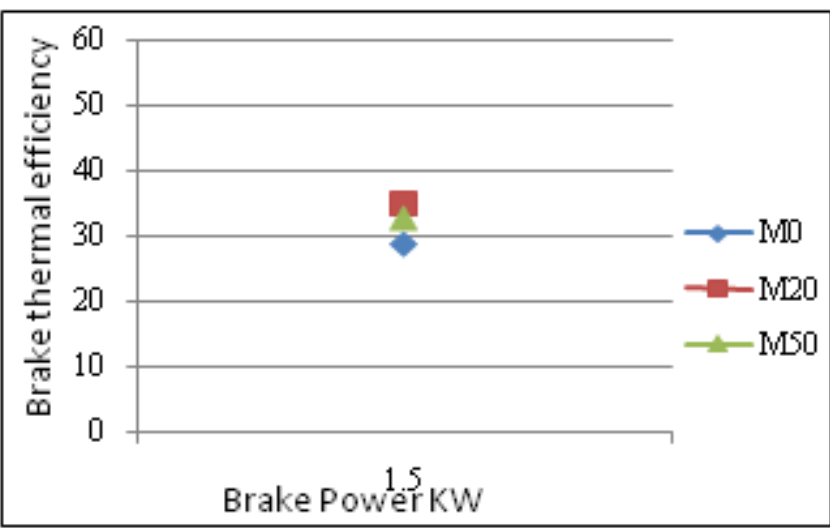

Figure 4: Variation of brake thermal efficiency (\%) with brake power

1) Effect on brake power:

Fig. 3 shows the brake power increases with increasing percentage of methanol-petrol blends at constant speed.

2) Effect on brake thermal efficiency :

According to the second law of thermodynamics, the engine thermal efficiency increases due to reduced heat loss from engine through heat transfer to atmosphere. Methanol has higher laminar flame propagation speed, which may fasten engine combustion process and thus improve engine thermal efficiency. M20 having higher brake thermal efficiency at constant engine speed.

\subsection{Testing terminology}

1) For Speed measurement, Tachometer can be used.

2) For fuel consumption, Rota meter can be used.

3) Indicated power,

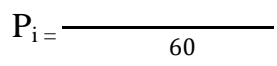

$\mathrm{P}_{\mathrm{i}=\frac{}{60}}=\frac{}{60} \mathrm{P}_{\mathrm{i}}=\mathrm{Ti} \quad \omega=\mathrm{Ti} \quad \frac{2 \pi}{60}$

$\mathrm{P}_{\mathrm{i}=} \frac{\text { 口 }}{60}$

Where:

Imep = is the indicated mean effective pressure $\left[\mathrm{N} / \mathrm{m}^{2}\right]$

$\mathrm{A}_{\mathrm{c}}=$ cylinder area $\left[\mathrm{m}^{2}\right]$

$\mathrm{L}=$ stroke length $[\mathrm{m}]$ 


\section{International Journal of Science and Research (IJSR) \\ ISSN (Online): 2319-7064}

Index Copernicus Value (2013): 6.14 | Impact Factor (2015): 6.391

$\mathrm{n}=$ number of cylinders

$\mathrm{N}=$ engine speed [rpm]

$\mathrm{z}=1$ (for 2 stroke engines), 2 (for 4 stroke engines)

$\mathrm{V}_{\mathrm{c}}=$ cylinder swept volume $\left[\mathrm{m}^{3}\right]$

$\mathrm{V}_{\mathrm{e}}=$ engine swept volume $\left[\mathrm{m}^{3}\right]$

$\mathrm{T}_{\mathrm{i}}=$ engine indicated torque $[\mathrm{Nm}]$

$\omega=$ engine angular speed $[1 / \mathrm{s}]$

\section{Brake power}

$\mathrm{BP}=\left(2 \prod \mathrm{NT}\right) / 60000 \mathrm{KW}$

\section{Mechanical Efficiency}

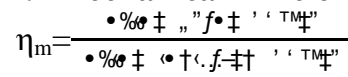

$\eta_{\mathrm{m}}=\frac{\mathbf{P b}}{\mathbf{P i}}=\frac{\text { 回 }}{\mathbf{P i}}=1-\frac{\mathbf{P b}}{\mathbf{P i}}$

Where:

$\eta_{\mathrm{m}}=$ mechanical efficiency

$\mathrm{P}_{\mathrm{b}}=$ engine brake power $[\mathrm{kW}]$

$\mathrm{P}_{\mathrm{i}}=$ engine indicated power $[\mathrm{kW}]$

$\mathrm{P}_{\mathrm{f}}=$ engine friction power $[\mathrm{kW}]$

\section{Indicated thermal efficiency}

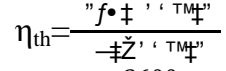

$$
\begin{aligned}
& \eta_{\text {th }}=-3600
\end{aligned}
$$

Where:

$\eta_{\text {th }}=$ thermal efficiency

$\mathrm{P}_{\mathrm{b}}=$ brake power $[\mathrm{kW}]$

$\mathrm{FC}=$ fuel consumption $[\mathrm{kg} / \mathrm{h}=$ (fuel consumption in $\mathrm{L} / \mathrm{h}) \mathrm{x}$ $(\rho$ in $\mathrm{kg} / \mathrm{L})]$

$\mathrm{CV}=$ calorific value of kilogram fuel $[\mathrm{kJ} / \mathrm{kg}]$

$\rho=$ relative density of fuel $[\mathrm{kg} / \mathrm{L}]$

\subsection{Benefits}

1) Using as a fuel in SI engines can offer an increased thermal efficiency and increased power output due to its high octane rating and high heat of vaporization.

2) It can be obtained from a number of sources, both natural and manufactured.

3) It can be used to help control internal engine temperatures and heat flows so as to reduce heat losses and thus raising fuel efficiency.

4) It is a high-octane fuel with anti-knock index numbers (octane number). Enginesusing high-octane fuel can run more efficiently by using higher compression ratios. It has higher flame speed.

5) This is very attractive for developing countries, because methanol can often be obtained from much cheaper biomass source than diesel oil.

\subsection{Conclusion}

In this study, it was seen that when engine was fueled with methanol-petrol blend, engine performance parameters such as brake torque, brake power, brake thermal efficiency, volumetric efficiency increases with increasing methanol amount in the blended fuel while bsfc and equivalence airfuel ratio decreased.
When the percentage of methanol increased then the fuel consumption is to be increased and efficiency is also decreases \&also when the percentage of methanol is to be less then fuel consumption and efficiency getting low. So, the average ratio of methanol-gasoline blend is must properly maintain.

Besed on performance of engine using M0, M20, M50 methanol petrol blends, optimum blend was found M20 (20\%methanol and $80 \%$ petrol).

\section{References}

[1] A. A. Abdel-Rahman and M.M. Osman, "Experimental investigation on varying the compression ratio of SI engine working under different ethanol-gasoline fuel blends", International Journal of Energy Research, vol. 21,pp. 31-40, 1997.

[2] Al-Hasan, M., "Effect of ethanol-unleaded gasoline blends on engine performance and exhaust emission", Energy Conversion and Management, vol. 44, pp. 15471561, 2003.

[3] F. Yüksel and B. Yüksel, "The use of ethanol-gasoline blends as a fuel in an SI engine", Renewable Energy, vol. 29, pp. 1181-1191, 2004.

[4] F.H. Palmer, "Vehicle performance of gasoline containing oxygenates", International Conference on Petroleum Based and Automotive Applications, London, UK: Institution of Mechanical Engineer's conference publications, MEP: 33 - 461986.

[5] H. Bayraktar, "Experimental and theoretical investigation of using gasoline-ethanol blends in sparkignition engines", Renewable Energy, vol. 30, pp.17331747, 2005.

[6] Kowalewicz, "Methanol as a fuel for spark ignition engines, a review and analysis", Proc. Institution of Mechanical Engineers, 1993207 (D1), pp. 43- 51, 1993.

[7] Liu Shenghua, Eddy R. Cuty Clemente, Hu Tiegang, Wei Yanjv, "Study of spark ignition engine fueled with methanol/gasoline fuel blends", Applied Thermal Engineering, vol. 27, pp. 1904-1910, 2007.

[8] M. BahattinÇelik, BülentÖzdalyan , FarukAlkan, The use of pure methanol as fuel at high compression ratio in a single cylinder gasoline engine, Fuel, vol. 90, pp. 1591-1598, 2011.

[9] O.C. Bridgeman, "Utilization of ethanol gasoline blends as motor fuels. Industrial Engineering Chemistry", vol. 28, pp.1102-1109, 1936.

[10] S.H. EI-Emam and A.A. Desoky, "A study on the combustion of alternative fuels in Spark-ignition engines", Journal of Hydrogen Energy, vol. 10, pp. $497-$ 504, 1985. 